\title{
The Existence of Carpet Industry in Bhadohi, India
}

\author{
Niladri Bihari Das, Rohit Kumar Sharma, Anand Pandey and Badri G Narayanan* \\ Purdue University, USA
}

*Corresponding author: Badri Narayanan G, Center for Global Trade Analysis, Purdue University, USA

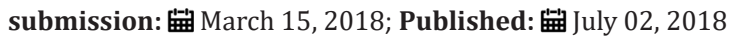

\begin{abstract}
Indian carpet is famous worldwide for its premium quality and texture. India controls almost 40 percentages of worldwide export volume. US is the largest importer of carpet from India in previous years. Bhadohi-Mirzapur region of Uttar Pradesh is famous for GABBE Woollen carpet in India and outside India. The carpet manufactured here are mainly export centric. This belt is famous from the age of Akbar regime. The Persian design is the primary attraction of the carpet manufactured here. The weavers are especially skilled to give the artistic form of the design with their hands to the carpet. But being the bottom of pyramid they get absolutely share of profit the businessmen and exporter company make. They are exploited by the middleman in every respect. The wages they get are so less that it makes them to leave the job and switch to other manual jobs. If a social enterprise or cooperative society could be setup them they could get the justice of being paid for what the labour they do.
\end{abstract}

Keywords: GABBE woollen carpet; Persian design, Social enterprise; Cooperative society

\section{Introduction}

The carpet weaving had been started way long back in 16th century in Mughal era.In current scenario India is the largest producer and exporter of carpet in the world in term of both volume and value. Approximately80 percent of carpet manufactured in India are exported. India is popular in global market for its excellent design especially Persian design. India has pioneered as largest exporter of handmade carpets. Hand-knotted woollen carpets, tufted woollen carpets, chain stitch rugs, pure silk carpets, synthetic carpets, handmade woollen durries are some of the demanding products in the European and American market. Exports of handmade carpet were 558.14 million USD in AprilJuly $2017^{1}$ [1]. India singlehandedly controls 40 percent of export worldwide. Indian carpet has market access in 73 countries $^{2}$ and US being the largest [2]. The carpet export promotion council is the apex body of exporters of the handmade carpet. The council help in terms of finding new market, refinancing activity, worldwide events participation, arranges international buyer seller meets and resolving trade disputes. Currently Rajasthan, Kashmir, Punjab, Uttar Pradesh, Andhra Pradesh and Himachal Pradesh are the major states in which carpet industry is flourished. The carpet industry has a huge growth potential but lack of innovation, out dated technology was considered as devil factors to prohibit
growth.To facilitate innovation and technology upgrade, Ministry of Textiles, Government of India set up the Indian Institute of carpet technology in Bhadohi, Uttar Pradesh in the year of 2001. It was first of its kind in Asia to develop human resource for the up gradation of the carpet industry in India. It has both national and international collaboration.

\section{Objective of study}

The objective of our study is

1. To understand the carpet industry in Bhadohi: Status of weavers

2. Find feasible solution to improve labour life

\section{Questionnaire}

Semi structured and unstructured interview was taken by us of the carpet weaver in the village Raipur and nearby village of Raipur of Bhadohi district of Uttar Pradesh. The following information we had collected.

\section{Basic information}

The respondent's name, age, highest educational qualification and number of dependant member on his/her earning were asked.

${ }^{1}$ Source: Carpet Export Promotion Council (CEPC), Department of Commerce.

${ }^{2}$ Source: India Brand Equity Foundation, https://www.ibef.org/exports/carpet-industry-in-india.aspx 


\section{Occupational information}

From how long the person is engaged in this occupation, what is the average wage he/she earn in how much working hours, willingness to work in this industry and alternative livelihood option available were asked. Also, the way they got the contract to work as labourer was asked.

\section{Process of Data Collection}

Data has been collected from following sources

\section{Primary source}

In this we had visited the household which are engaged now and engaged before in carpet weaving job. Semi structured and unstructured interview were taken.

\section{Secondary source}

Data has been collected from various online resources available like Central Export Promotion Council's website, India Brand Equity Foundation's website etc.

\section{Indian Carpet Industry \\ History of carpet in India ${ }^{3}$}

Presence of carpets could be traced into 500 B.C. in Indian subcontinents. We can find the mention of floor covering and mats in medieval Indian literature [1].Babur came to India and missed the Persian carpet too much. Thus, Akbar introduced Persian design carpet weaving in India in 1580 A.D. in Agra palace. Mughal carpetswere as obscure as their miniatures and usually depicted court life, animals and floral decorations. Mughal carpets were brightly coloured and the hand knotted silk carpets had 4224 knots per square inch. But the pie carpet was dominant in that time. From the beginning, wool or silk was the prime material for carpet weaving. Wool carpet has a diversified origin but the silk knots are used in Kashmir region.The patterns of Indian carpets varied from vines and floral patterns, animal and bird figures and geometric and calligraphic patterns.Rugs from Akbar's reign started using cotton wrap and wool pile and a colour scheme made up of multiple shades of blues, greens and other colours on a red or peach base. The patterns were just replica of Persian style and customised for Indian culture and tastes.During Jahangir's reign (1605-27) were more magnificent. Usage of silk and pashmina permitted more number of knots resulting more tight texture. These patterns led to more miniature paintings. Subtle gradations and shadings with yarns were themselves artistic. The patterns of these carpets were a reflection of manuscript paintings. From this time, the Indian carpet showed technically refined taste in design and construction. He carpets had scrolling vines, flowering plants, and more naturalistic animals in pictorial or overall pattern.During Shahjahan's ruling (1628-58) the Indian carpet had attained new heights. 2000 knots per square inch was introduced using silk yarns. Velvety like texture was attained using silk or pashmina piles. Yarn shading was as stylish as in Jahangir`s reign. Flower design was prevalent in this time. Yarn shading was as stylish as in Jahangir`s reign. During this time,Chinese and European patterns also influenced the Indian carpet. Calligraphy influenced the carpet craft as it did the other crafts in India.In 1958 there were 14 factories with 350 looms and 80 cottage units with 400 looms.According to a survey in India, there were about 3500 carpet weavers in 1974.By the end of eighties their total number reached about 48000 people.

\section{Types of carpet in India 4}

Synthetic carpets: These carpets are made up of synthetic fibres. It delivers superior strength when compared to natural fibre carpets. It has a wide application in military, industry and horticultures. Synthetic carpets are not human health friendly.

Pure silk carpets: Made up of completely from silk and captures a great human imagination.In most carpet belts, manufacturing and weaving silk carpets is a family business where the secrets and techniques are transferred from one generation to the following ones.

GABBE woollen carpet: These carpets are predominantly produced in the Bhadohi- Mirzapur regions of Uttar Pradesh. This kind of carpet uses indigenous and unique tradition of various tribal patterns, which are very antique and elegant in design. These carpets are costliest in the market with comparison to all other available in India. It is believed that it's generally made of $25 \%$ cotton and $75 \%$ wool but actual composition is still unknown.

Tufted woollen carpets: These types of carpets are made by both hand and machine. These types of rugs can be produced easily and inexpensively. It has more colour variety and patterns. It is the best-looking carpet in market. It contributes more to the export volumes.

Handmade woollen durries: These types of carpet are made up of the finest wool resulting look better and beautiful. These carpets can be weaved only by some specific communities living in the inlands of India. These carpets are custom made according to the required design and quality of the clients.

Wool chain stitch rugs: These rugs are made by loosely twisting the yarn on cotton or linen based materials. These types of rugs are very famous and are placed at most of the museum and exhibition around the world.Rotating from the centre, the rows of this type of rugs create solid and stylish patterns making a clear embossed feeling to add different textures.

Hand-knotted woollen carpets:Well-liked for its elegant style and unique craftsmanship, these types of carpets are adored all around the world. There are many carpet manufacturers who offer customized carpets for clients as they require.

${ }^{3}$ Source: Carpet Export Promotion Council, http://www.indiancarpets.com/carpet-history.html

${ }^{4}$ Source: Carpet Export Promotion Council, http://www.indiancarpets.com/carpet-type.html 


\section{Carpet export from India ${ }^{5}$}

From the above export data(Table 1)[3], we can see in the financial year 2015-16 US was the top importer of carpet resulting
40 percentage contribution and UK being the second highest resulting 14 percentage contribution(Figure 1).

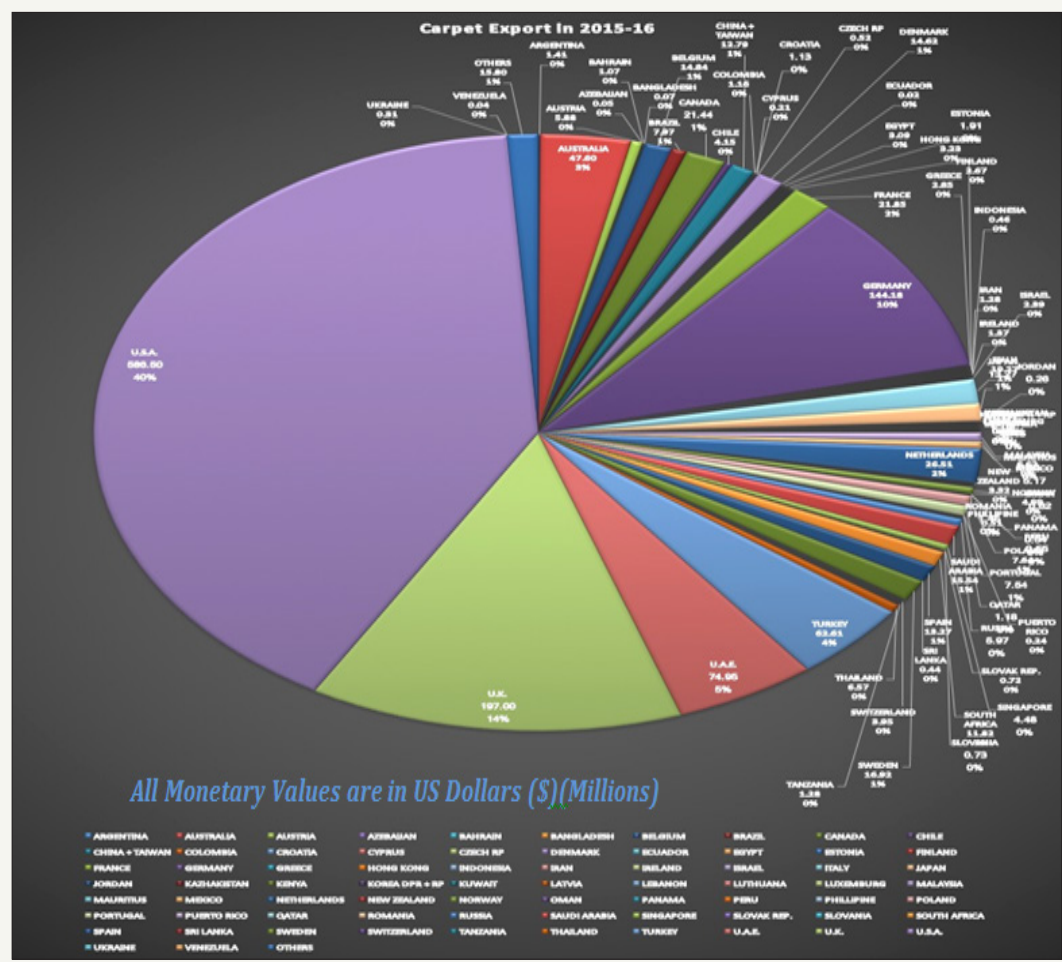

Figure 1:

Tables 1:

\begin{tabular}{|c|c|c|c|c|c|c|}
\hline \multicolumn{7}{|c|}{ Country-Wise Exports of Handmade Carpets \& Other Floor Coverings } \\
During 2013-14, 2014-15 \& 2015-16 \\
\hline \multicolumn{2}{|c|}{} \\
\cline { 3 - 9 }
\end{tabular}

${ }^{5}$ Source: Carpet Export Promotion Council, http://www.indiancarpets.com/statistics.html 


\begin{tabular}{|c|c|c|c|c|c|c|c|}
\hline 9 & Canada & 141.19 & 23.34 & 131.24 & 21.46 & 140.37 & 21.44 \\
\hline 10 & Chile & 17.04 & 2.82 & 13.18 & 2.16 & 27.14 & 4.15 \\
\hline 11 & China+Taiwan & 45.71 & 7.56 & 62.67 & 10.25 & 83.73 & 12.79 \\
\hline 12 & Colombia & 8.74 & 1.44 & 8.70 & 1.42 & 7.58 & 1.16 \\
\hline 13 & Croatia & 3.85 & 0.64 & 4.60 & 0.75 & 7.40 & 1.13 \\
\hline 14 & Cyprus & 0.63 & 0.10 & 1.59 & 0.26 & 1.38 & 0.21 \\
\hline 15 & Czech RP & 2.87 & 0.47 & 2.57 & 0.42 & 3.39 & 0.52 \\
\hline 16 & Denmark & 72.57 & 11.99 & 83.30 & 13.62 & 95.72 & 14.62 \\
\hline 17 & Ecuador & 2.28 & 0.38 & 0.57 & 0.09 & 0.14 & 0.02 \\
\hline 18 & Egypt & 9.02 & 1.49 & 20.21 & 3.31 & 20.23 & 3.09 \\
\hline 19 & Estonia & 11.36 & 1.88 & 0.97 & 0.16 & 12.53 & 1.91 \\
\hline 20 & Finland & 21.63 & 3.58 & 17.17 & 2.81 & 17.46 & 2.67 \\
\hline 21 & France & 12.04 & 1.99 & 103.07 & 16.86 & 143.06 & 21.85 \\
\hline 22 & Germany & 665.51 & 110.00 & 680.25 & 111.25 & 943.94 & 144.18 \\
\hline 23 & Greece & 14.46 & 2.39 & 16.59 & 2.71 & 18.69 & 2.85 \\
\hline 24 & Hong Kong & 10.13 & 1.67 & 19.37 & 3.17 & 21.15 & 3.23 \\
\hline 25 & Indonesia & 1.07 & 0.18 & 4.72 & 0.77 & 3.03 & 0.46 \\
\hline 26 & Iran & 2.11 & 0.35 & 9.77 & 1.60 & 8.39 & 1.28 \\
\hline 27 & Ireland & 5.72 & 0.95 & 3.61 & 0.59 & 9.00 & 1.37 \\
\hline 28 & Israel & 12.09 & 2.00 & 22.44 & 3.67 & 15.65 & 2.39 \\
\hline 29 & Italy & 98.89 & 16.34 & 102.24 & 16.72 & 126.18 & 19.27 \\
\hline 30 & Japan & 75.02 & 12.40 & 68.24 & 11.16 & 86.89 & 13.27 \\
\hline 31 & Jordan & 37.90 & 6.26 & 1.18 & 0.19 & 1.72 & 0.26 \\
\hline 32 & Kazhakistan & 0.95 & 0.16 & 1.41 & 0.23 & 0.68 & 0.10 \\
\hline 33 & Kenya & 1.68 & 0.28 & 9.96 & 1.63 & 1.66 & 0.25 \\
\hline 34 & Korea DPR + RP & 15.41 & 2.55 & 28.03 & 4.58 & 17.77 & 2.71 \\
\hline 35 & Kuwait & 11.96 & 1.98 & 18.02 & 2.95 & 13.31 & 2.03 \\
\hline 36 & Latvia & 15.87 & 2.62 & 11.45 & 1.87 & 7.35 & 1.12 \\
\hline 37 & Lebanon & 9.46 & 1.56 & 12.06 & 1.97 & 14.39 & 2.20 \\
\hline 38 & Luthuana & 2.72 & 0.45 & 8.06 & 1.32 & 3.70 & 0.57 \\
\hline 39 & Luxemburg & 1.87 & 0.31 & 0.87 & 0.14 & 0.97 & 0.15 \\
\hline 40 & Malaysia & 23.25 & 3.84 & 66.44 & 10.87 & 43.35 & 6.62 \\
\hline 41 & Mauritius & 5.74 & 0.95 & 2.63 & 0.43 & 1.97 & 0.30 \\
\hline 42 & Mexico & 21.41 & 3.54 & 21.68 & 3.55 & 33.86 & 5.17 \\
\hline 43 & Netherlands & 113.74 & 18.80 & 141.79 & 23.19 & 173.56 & 26.51 \\
\hline 44 & New Zealand & 16.82 & 2.78 & 18.28 & 2.98 & 21.74 & 3.32 \\
\hline 45 & Norway & 29.15 & 4.82 & 31.61 & 5.17 & 32.64 & 4.99 \\
\hline 46 & Oman & 6.07 & 1.00 & 4.65 & 0.76 & 4.04 & 0.62 \\
\hline 47 & Panama & 6.76 & 1.12 & 8.01 & 1.31 & 3.52 & 0.54 \\
\hline 48 & Peru & 2.31 & 0.38 & 1.91 & 0.31 & 3.61 & 0.55 \\
\hline 49 & Phillipine & 1.33 & 0.22 & 3.09 & 0.51 & 3.37 & 0.51 \\
\hline 50 & Poland & 27.36 & 4.52 & 22.32 & 3.65 & 50.03 & 7.64 \\
\hline
\end{tabular}




\begin{tabular}{|c|c|c|c|c|c|c|c|}
\hline 51 & Portugal & 37.84 & 6.25 & 40.84 & 6.68 & 49.37 & 7.54 \\
\hline 52 & Puerto Rico & 1.53 & 0.25 & 0.78 & 0.13 & 1.56 & 0.24 \\
\hline 53 & Qatar & 29.24 & 4.83 & 25.17 & 4.12 & 7.72 & 1.18 \\
\hline 54 & Romania & 8.44 & 1.39 & 3.22 & 0.53 & 9.51 & 1.45 \\
\hline 55 & Russia & 40.10 & 6.63 & 31.82 & 5.20 & 39.07 & 5.97 \\
\hline 56 & Saudi Arabia & 54.27 & 8.97 & 62.06 & 10.15 & 101.74 & 15.54 \\
\hline 57 & Singapore & 34.99 & 5.78 & 25.46 & 4.16 & 29.32 & 4.48 \\
\hline 58 & Slovak Rep. & 1.43 & 0.24 & 2.38 & 0.39 & 4.69 & 0.72 \\
\hline 59 & Slovania & 4.94 & 0.82 & 7.72 & 1.26 & 4.79 & 0.73 \\
\hline 60 & South Africa & 58.98 & 9.75 & 57.60 & 9.42 & 77.37 & 11.82 \\
\hline 61 & Spain & 61.05 & 10.09 & 54.93 & 8.98 & 86.87 & 13.27 \\
\hline 62 & Sri Lanka & 2.11 & 0.35 & 19.15 & 3.13 & 2.87 & 0.44 \\
\hline 63 & Sweden & 67.52 & 11.16 & 82.55 & 13.50 & 110.69 & 16.92 \\
\hline 64 & Switzerland & 21.92 & 3.62 & 21.35 & 3.49 & 25.86 & 3.95 \\
\hline 65 & Tanzania & 0.60 & 0.10 & 2.99 & 0.49 & 8.36 & 1.28 \\
\hline 66 & Thailand & 25.37 & 4.19 & 32.78 & 5.36 & 43.00 & 6.57 \\
\hline 67 & Turkey & 234.59 & 38.77 & 166.17 & 27.18 & 409.91 & 62.61 \\
\hline 68 & UAE & 648.87 & 107.25 & 1309.89 & 214.23 & 490.70 & 74.95 \\
\hline 69 & UK & 484.49 & 80.08 & 457.88 & 74.89 & 1289.71 & 197.00 \\
\hline 70 & USA & 3117.22 & 515.23 & 3701.81 & 605.43 & 3839.70 & 586.50 \\
\hline 71 & Ukraine & 3.00 & 0.50 & 1.65 & 0.27 & 2.02 & 0.31 \\
\hline 72 & Venezuela & 3.98 & 0.66 & 1.20 & 0.20 & 0.29 & 0.04 \\
\hline \multirow[t]{2}{*}{73} & Others & 144.77 & 23.93 & 104.11 & 17.03 & 103.41 & 15.80 \\
\hline & Total & 7108.31 & 1174.89 & 8441.95 & 1380.67 & 9481.36 & 1448.24 \\
\hline
\end{tabular}

*Source: DGCI\&S [3]

\section{Carpet Industry in Bhadohi}

\section{Background of Bhadohi}

Bhadohi carpet is famous for its various knots and counts designs. This belt specialises in Woollen, Tufted, Tibetan Carpet and Durries. The whole belt of production spread over 1000 square kilometres ${ }^{6}$ and many villager's livelihood is completely dependent on the carpet industry.The Indian Institute of Carpet Technology, the only Institute of its kind in Asia was established here by the Ministry of Textiles in 2001. The town of Bhadohi, which gives its name to the Pargana and the Tahsil, is situated in Lat $25^{\circ} 23^{\prime} \mathrm{N}$. and Long $82^{\circ} 34^{\prime} \mathrm{E}^{7}$ at the distance about thirty miles from west of Varanasi, twelve miles north-east of Gopiganj and about three miles south of the river Varuna. It is connected with Jaunpur by a provincial highway and with Gopiganj by a mettaled road running via. Gyanpur connecting the road from Bhadohi to Suriawan and Parsipur.

\section{History $^{8}$}

Bhadohi and its adjoining areas have no production or availability of various raw materials used in carpet making but these are the places where the carpet industry was founded and flourished tremendously[4]. The ancient history of carpet making in India goes long back and it was Emperor Jahangir was contemporary of Shah Abbas of Iran. Both the kings were friends. It is a well-known historical fact that during the regime of Shah Abbas, the carpet industry made a spectacular progress. He took special interest in developing new attractive designs and some of them are popular even today. Emperor Jahangir ruled India in the $16^{\text {th }}$ century A.D and his capital was Akbarabad (Agra) where he encouraged this handicraft. After 1857A.D war of freedom which was named by Britishers as Mutiny, Agra, Delhi and other places were full of turmoil and subsequently a number of carpet weavers fled from Agra and got shelter in the village of Madhosingh on the G.T. road

${ }^{6}$ Source: Carpet Export Promotion Council, http://www.indiancarpets.com/carpet-belts.html

${ }^{7}$ Source: Google Map

${ }^{8}$ Source: http://shodhganga.inflibnet.ac.in:8080/jspui/bitstream/10603/110774/9/12_chapter3.pdf 
located between Bhadohi and Mirzapur and started carpet weaving on a very small scale. Perhaps it was during the late $19^{\text {th }}$ century that one Mr. Brownford noticed those making carpets and realized its economic viability and decided to establish a company under the name and style of M/s. E. Hill \& Co. in the small village of Khamaria. It was followed by Mr. A. Tellery who got his factory established in Bhadohi. His eldest son Mr. Brownford noticed those making carpets and realized its economic viability and decided to establish a company under the name and style of M/s. E. Hill \& Co. in the small village of Khamaria. It was followed by Mr. A. Tellery who got his factory established in Bhadohi. His eldest son Mr. Otto Tellery was one of the founder members of the All India Carpet Manufacturers Association and was the first president of the organization. Next to these two gentlemen, a group of three Europeans formed a company by the name of $\mathrm{M} / \mathrm{s}$ Obeettee. The group comprised of Messrs. Oklay, Bowden and Tallor the abbreviation of these three is Obeettee.

\section{Production process ${ }^{9}$}

The production follows these following steps.

Designing: It's the first step toward a beautiful and elegant looking carpet. It's little bit high paying job as compare other labourintensive job in this industry. The designer is called nakshakar. The

\section{Labour life in carpet industry, Bhadohi ${ }^{10}$}

nakshakarexpresses his imagination in a hard paper sheet or cloth piece. The weaver will follow the design to weave.

Dyeing: The dyeing of wool is a delicate process which varies according to the dyestuff used and the colour desired. Commercially this process is directed by a master dyer, who is highly skilled and respected craftsman in a profession that demands accuracy as well as skill. This process is accomplished in hot chamber for even dyeing of wools. And then the wools are dried in open space under the sun.

Process of weaving:The weaver then gets the mixed up and cross puzzled wool bundle measured in kilogram from a contractor. Then they employ themselves or women or children of the family to open them up to proper threads of desired thickness and strands. Then they weave the carpet using the katharrangement.

Washing: After the weaving process is completed the contractor takes the carpet back again measured in kilogram. Then the carpet is being washed thoroughly to wash out the dusts and extra cotton and wool micro-particles.

Finishing and packaging:Then the carpet is further subjected to inspection for texture and colour evenness of design. After they do some manual adjustment it proceeds for packing and shipping.

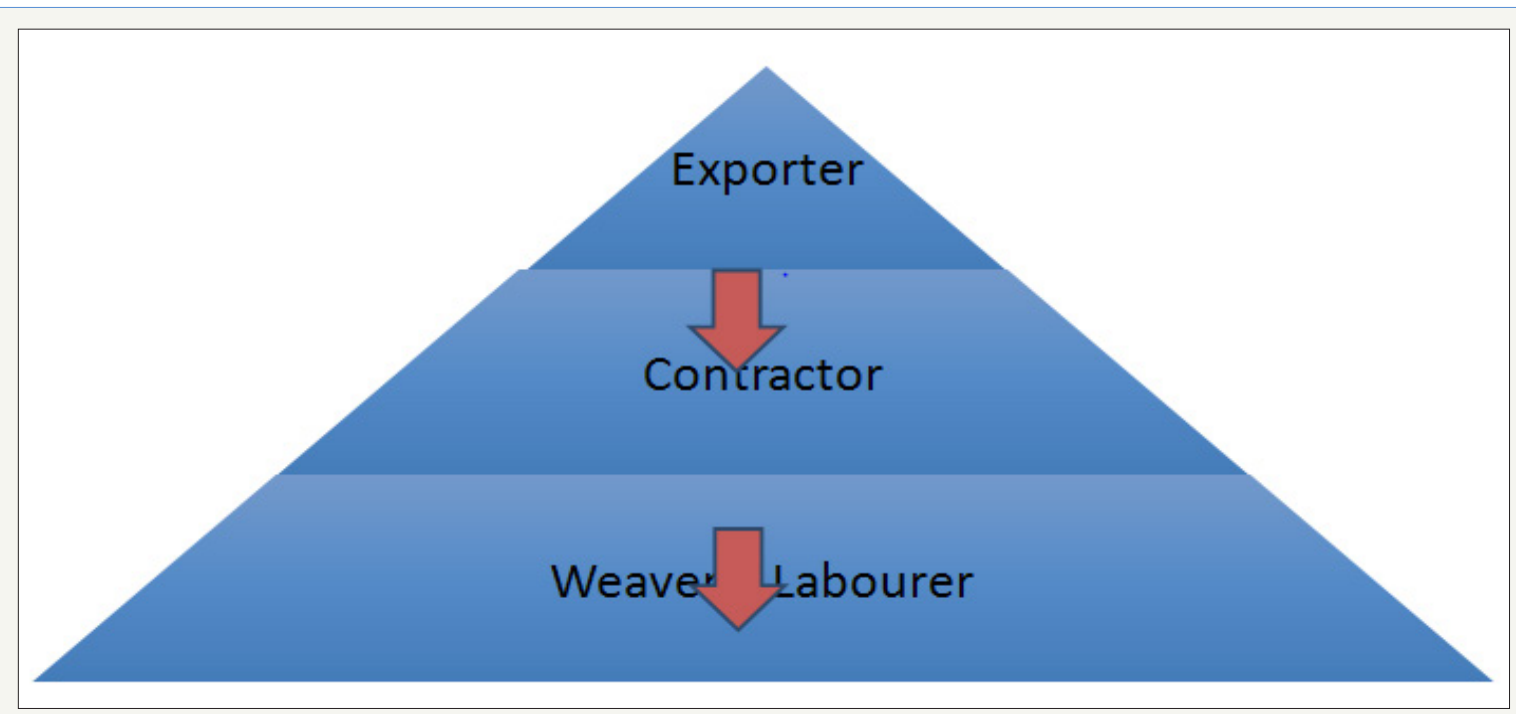

Figure 2:

Work flow: The carpet industry has employed a wide range people with respect to age, gender and caste. The backward classes are employed as the skilled and semi-skilled labourer in most of the cases. The upper-class people predominantly male are employed as the middle man, designer or the business entity holder. So there always exists a caste disparity in the village level of the carpet industry hierarchy. In general, the exporter got the purchase order from a customer and got approved with the design of the carpet from them. Then they choose a middle man (Contractor) to get the work done from ground level workers. They provide the contract of manufacturing to the contractor with required amount of dyed wool, yarns, transportation charge and fund for wages and his own cut. The contactor then gets in touch with the weavers who have installedkathin their premise and has employed some labourer to work with him(Figure 2).

${ }^{9}$ Source: Primary Unstructured Interview, December, 2017

${ }^{10}$ Source: Primary survey, December, 2017. 
The contractor gives them the mixed of yarn and wool. Then the weaver employs some persons to untie these raw materials(Kati) into threads suitable for weaving, especially women of the households do this job. After they get the thread, they mount yarn and wool as required to the kath. The weaver also hires some labourer to work with him and some family members also got associated with it.

Wage: The amount the weaver gets is on the basic of amount carpet being prepared. And for unwrapping and untying of yarn the labourers get wage according to weight of thread resulted.

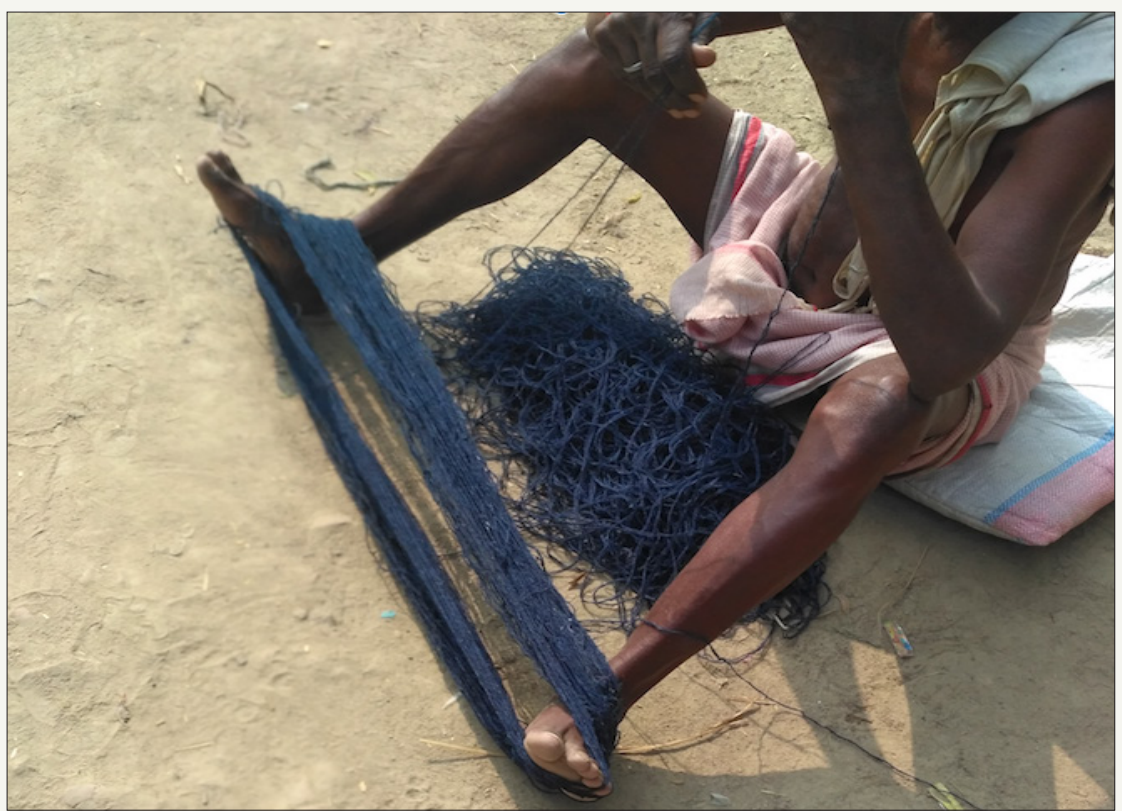

Figure 3: A person opening 'kati'.

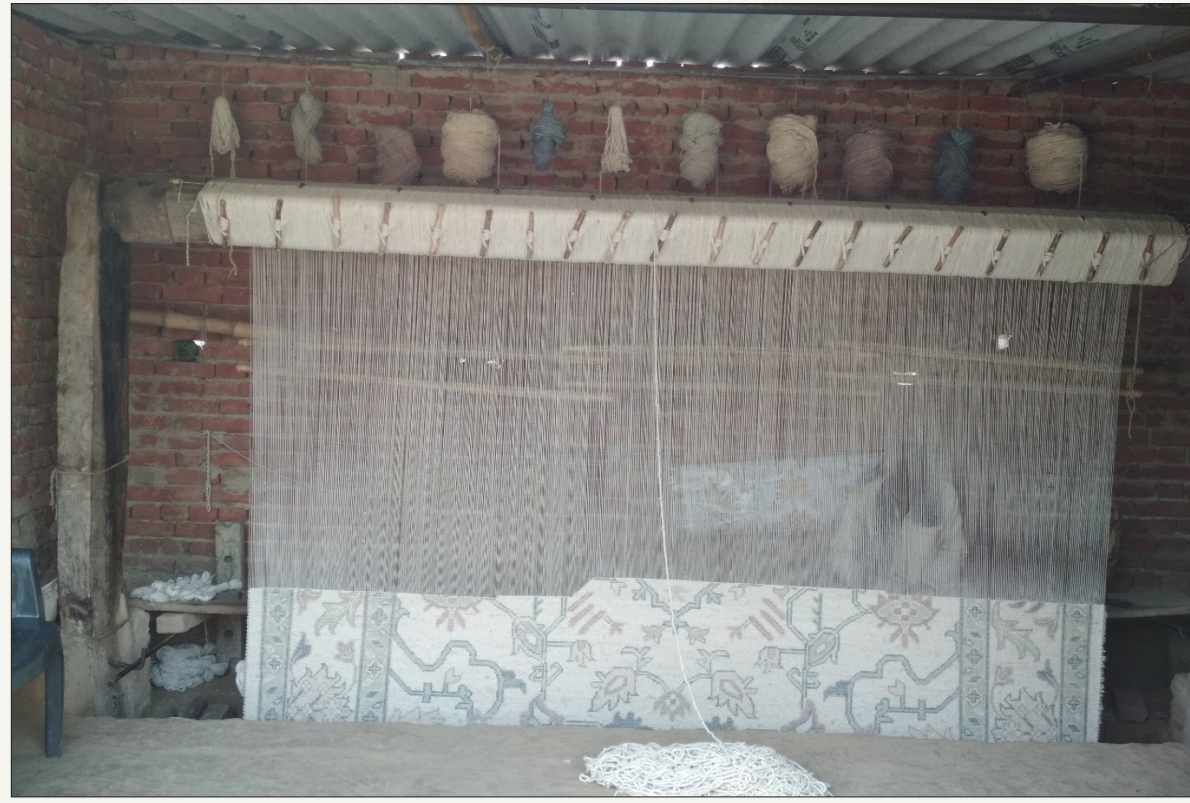

Figure 4: A weaver is weaving the carpet.

While the weavers get 1200-1800 INR for 1 Foot*9Feet depending the quality of the carpet, the women work for untying on an average 60-70 INR per day depending upon the contactor fund availability. A full carpet is of dimension 6.5Feet * 9Feet(Figure 3 \& 4).

Skilled labour wage: The weavers, who are skilled with working using Tufted guns earns bit more per day as they could do more work in one day with respect to the manual weaver. They earn in a range of 200-350 INR per day depending upon the thickness of carpet they are working with. They normally work for companies directly and contractors also.

Semi-skilled labour wage: They generally work at their home and nearby premises. They could earn as much as 100-150 INR per day. They do all work by hand, so too much slow to complete the full carpet. They take as much as 30-40 days to complete a full carpet. 
Unskilled Labourer: These are the labourer who work for untying the wools and transportation worker. They are paid very less amount. They don't have any contract, rather they work on demand.

\section{Migration $^{11}$}

Out bound migration is happening of youths. Possible reason as per the respondents.

1. Low wages in hand-made carpet industry

2. Unable to generate sufficient job with growing population

3. Wage exploitation by the contractors

4. No job security available

Low wage: In the condition where price of every day to day use commodity is increasing, the wage to work in the handmade carpet has not been increased as par. It's difficult to feed and educate children and also to sustain family.

Less job generation: The family size is increasing day by day, more youth are coming out to the job market. But the carpet industry has not generated much job to accommodate these new comers. Also, utilization of machines has also further squeezed the new job generation.

Wage exploitation: The weavers get money when they complete the job as per the condition with the contractor. But the irony is when it's the time to pay the wage to the weaver the contractor also plays many times. Either they give less than they promised or they delay the payment so much that it's become really hard to sustain family unless they have and alternative livelihood options.

Job security: This industry does not provide job security, employee benefit scheme and medical finance assistance to the weavers and ground level labourer. Thus, new generation youth are not willing to work with this industry at the village level. They are willing to do private job at some companies at Mumbai or Delhi peripheral areas.

\section{Suggestions}

In the purview of the above scenario there are few suggestions on which organization can plan its intervention.

\section{Concept of cooperative}

A cooperative is "an autonomous association of persons united voluntarily to meet their common economic, social, and cultural needs and aspirations through a jointly-owned and democraticallycontrolled enterprise"12.

\footnotetext{
${ }^{11}$ Source: Field Survey, December, 2017.

${ }^{12}$ Source: Wikipedia, https://en.wikipedia.org/wiki/Cooperative

${ }^{13}$ Source: https://www.thenews.coop/108666/sector/community/should-co-ops-call-themselves-social-enterprises/
}

The organisation could mobilise weavers to form their own company completed managed by the stakeholders i.e. the weavers. For the first few years the organisation intervening have to stay attached to the weavers' cooperative and help them hire marketing and technology professional. For funding the organisation could help the cooperative secure loan from bank of micro financing agency in a joint liability mode.

\section{A. Advantages}

In this mode of working the weaver and labourer will get proper wage and also the profit of their work will be shared among themselves. They can further expand their business and employ more people depending upon the requirement and finance available to pay the employee.

\section{B. Disadvantages}

This model may fail if the intervening organisation withdrawsthem prematurely. The weavers are normally not so much to run a company. It will take generation to train them to do businesses. Their next generation may not be interested to work in this sector. To convince the people to form a cooperative is hard.

\section{Concept of social enterprise}

Social enterprises are businesses that tackle social problems, improve communities, provide people access to employment and training or help the environment. According to Freer Spreckley, an enterprise may be called "social" if it is owned by those who work and/or reside in a given locality or is governed by registered social as well as commercial aims and is run co-operatively.

Another definition, given by Kim Alter, sees social enterprises as businesses created for a social purpose to mitigate or reduce a social problem or market failure, and to generate social value while showing innovation ${ }^{13}$.

Social enterprise defines itself as an organization that:

a) Are driven by public or community cause, be it social, cultural, environmental or economic

b) Derive most of their income from trade, not donations or grants

c) Use the majority (at-least 50\%) of their profits to work towards their social mission.

Aim: The aim of social enterprise is to achieve both a social return on investment and a financial return on investment thus working towards blending value return on investment(Figure 5).There are many non-profit organizations that operate social enterprises. Their aim is to fill a community need in the market, advance their mission and contribute to financial sustainability. 


\section{Social return on investment i.e. Non-profit}

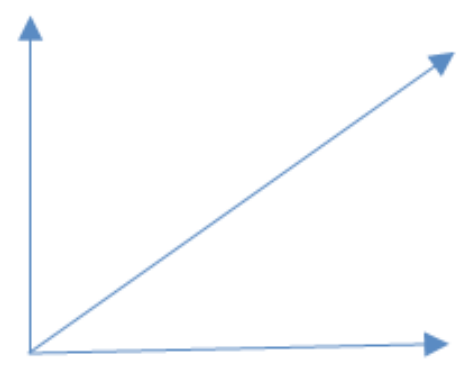

\section{Blended value return on investment i.e. Social enterprise}

\section{Financial return on investment i.e. Traditional business}

Figure 5:

Models of social enterprise: There are three models of social enterprise

A. Subsidized social enterprise:These businesses depend on subsidized funding to support operational costs. i.e. training subsidies.

B. Self-sustaining social enterprise:These businesses do not receive any grants, though are able to cover operational costs fully with sales revenue.

C. Profitable social enterprise:These businesses have income that exceeds expenses and are therefore profitable operation social enterprise.

\section{Non-profit continuum ${ }^{14}$ (Figure 6)}

Different kinds of social enterprise ${ }^{15}$ :

A. Community Enterprises: Enterprises which serve a particular geographical community or community of interest and have representatives from the community on their board of directors.
B. Social Firms: Aim to integrate people who might otherwise find it difficult in the mainstream job market, such as people with learning disabilities or mental health problems.

C. Co-operatives: Organisation owned, controlled, and run for the benefit of their members.

D. Credit Unions: These are community based financial institutions that provides savings and loan facilities for their members.

E. Community Development Finance Institutions: They are the providers of loans and other types of investment primarily for social enterprises and other small businesses.

A. Development Trusts: They are community enterprises which aim to develop a community, usually through the ownership and management of property.

B. Public sector spin-outs: They are the independent social enterprises set up to deliver services that were previously provided by public sector organisations. They are also known as 'externalised' services.

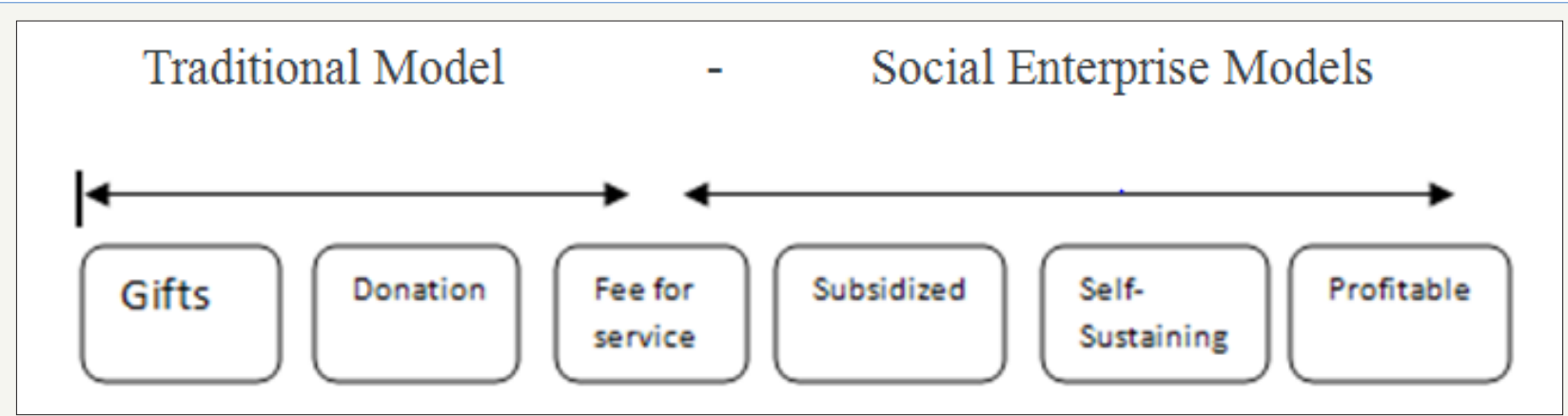

Figure 6:

\footnotetext{
${ }^{14}$ Source: https://www.gov.mb.ca/jec/social_enterprise/types.html

${ }^{15}$ Source: http://www.cwcda.co.uk/Social-enterprise/Different-types-of-Social-Enterprises
} 
C. Trading arms of charities: These are set up to undertake trading activity in order to raise money for their charity parent company e.g. charity shops, catalogues, training and consultancy.

D. Fair Trade organisations: They are committed to ensure that producers are paid a fair price for what they produce.

E. Other types of social enterprise: Businesses with social objectives as central as their economic objectives.

Organisation could facilitate entrepreneur or could jump by itself from own funding or external funding to form a business entity to achieve a social goal of improving the life style the village level weaver and labourer offering them a fair wage and better employee benefit scheme such as health insurance, educational assistance to their children etc.

\section{Conclusion}

Since there is a very low demand for carpet in India due to which labourers have stopped working. There are several reasons for the labourers to prevent making carpets one of them is that the wages are very low and secondly they don't have any market skills to improve their business. As the idea of making carpets was originated from India, there should be complete attention and focus given to the carpet industry. Different kinds of institutes have to be made where the students could be taught and given knowledge about the carpetsand this will bring employment for several people in India. If proper skills are provided to the ground level labourers then it will upgrade a better income and bring a better livelihood for them.

\section{References}

1. Carpet Export Promotion Council (CEPC) (2018) Statistics on carpet exports from India. Department of Commerce, Government of India, India.

2. India Brand Equity Foundation (IBEF) (2018) Carpet exports from India.

3. Directorate General of Commercial Intelligence and Statistics (DGCI\&S) (2018) Export import data bank.

4. Karimi A (2016) Bhadohi carpet industry: Dynamics of social exclusion. PhD Thesis, Aligarh Muslim University, India.
Creative Commons Attribution 4.0

International License

For possible submissions Click Here
Submit Article

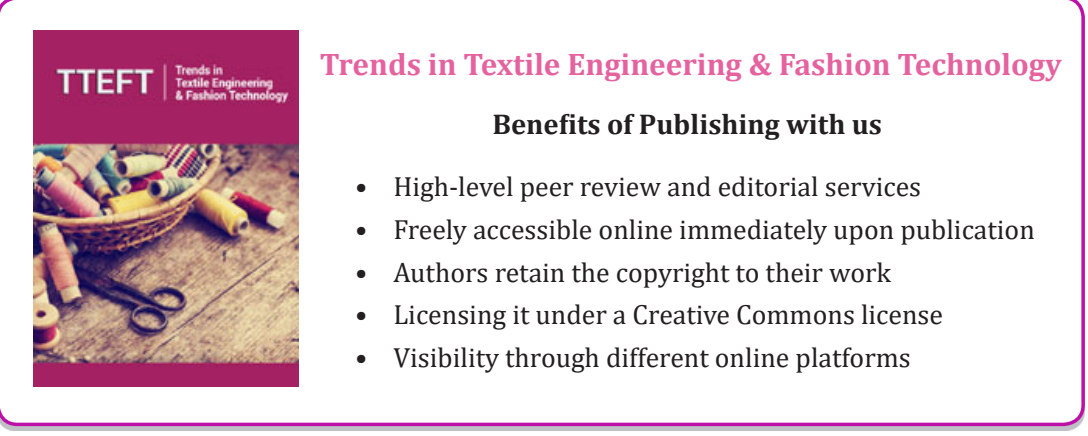

